\title{
Editorial
}

\section{Novos desafios}

Em um tempo tão exigente, no qual as escolhas políticas prolongam e aprofundam o sofrimento que decorre da pandemia da Covid-19, a Revista Laborare tem muito orgulho de publicar essa nova edição. Nossa revista tem se tornado referência para quem lida com questões relacionadas ao mundo do trabalho, desde uma perspectiva crítica e transformadora.

Nessa edição, além de dois artigos sobre os efeitos da "reforma" em relação à segurança e saúde no trabalho e à escravização contemporânea, temos também um Dossiê com dez artigos ligados ao tema Trabalho e Informalidade, sob a coordenação da Editora Especial, Professora Renata Dutra, da UnB.

Os temas dialogam, afinal a informalidade tem potencializado não só a precarização das condições de existência das trabalhadoras e trabalhadores, mas também sua saúde.

Trabalho digno é, inclusive, uma expressão de luta por uma sociedade diversa, pois a verdade é que a obrigação de trabalhar, como modo praticamente exclusivo de obter salário e, com isso, alimento, remédio, roupa e moradia, faz do trabalho um modo de sujeição. Reivindicar o respeito à dignidade de quem dele vive, o que implica efetivar direitos sociais (previdenciários e trabalhistas), é o primeiro passo para garantir condições materiais de existência que permitam a formulação e a construção de outras formas de sociabilidade.

Daí a importância de textos que discutem ambientes de trabalho nos quais o Direito do Trabalho não entra. Travestis, vendedoras de acarajé ou de cosméticos, trabalhadores das 
ruas e das plataformas digitais, elas e eles tm cor, gênero e classe. A intersecção dessas opressões, tão bem analisada nos artigos aqui apresentados, mal disfarça a raiz comum do colonialismo predatório que marca nossa história e explica a resistência que temos em enfrentar questões estruturais. Estamos em 2022, mas o racismo e o sexismo seguem presentes como marcadores importantes da precarização de alguns tipos específicos de trabalho.

A importância das discussões aqui travadas pode ser dimensionada por notícias recentes de trabalhadores espancados ou mortos por reclamarem a falta de salário. Essa espécie de retorno à barbárie é sinal de uma realidade ainda mais triste: nunca saímos dela. Por isso, não conseguimos efetivar direitos que estão lá na Constituição desde 1988, insistimos em absurdos como a prática de justa causa ou de aplicação de penalidades no ambiente de trabalho. Por isso, naturalizamos a precarização e convivemos com esses espaços nos quais as duras conquistas sociais simplesmente não existem como realidade.

A situação dos entregadores de aplicativo é talvez a mais aparente, mas não é a única, nem a mais grave. E, com certeza, não é a mais antiga. Articular-se coletivamente, como propõe um dos autores, é essencial. É na luta que as condições sociais se alteram. E nesse sentido, os entregadores por aplicativo tem uma importante lição de organização e luta a nos ensinar.

O teletrabalho, que com a pandemia passou a constituir uma aposta, é outro assunto essencial, pois, a aceleração dessa forma atomizada e invisibilizada de trabalhar tem repercussões que extrapolam a esfera individual ou física. Atingem as relações sociais, a forma como nos compreendemos no mundo e como existimos, inclusive politicamente.

A leitura dessa edição da Laborare contribui muito para refletir sobre a precarização e a informalidade do trabalho, desde uma perspectiva crítica e comprometida com mudanças em busca do trabalho digno. 


\section{Editorial: Novos desafios}

Essa edição é especial, não apenas em razão dos temas abordados e da qualidade dos artigos, mas também porque marca um novo ciclo da revista - encerra o período do médico Fernando Donato Vasconcelos como editor-geral da Laborare, iniciado em 2018 com a edição $n^{\circ} 1$ e que perdurou por quatro anos e com muitos êxitos.

À frente da Laborare seguirá a juíza do trabalho e professora Valdete Souto Severo, que iniciou como coeditora-geral no $\mathrm{n}^{\circ}$ 4, em 2020, que, a partir da próxima edição, terá como coeditor-geral o auditor-fiscal do trabalho Emerson Victor Hugo Costa de Sá. Ambos têm o desafio de consolidar a publicação, inclusive no que se refere à indexação.

Boa leitura! 